\title{
Selector Valve Device
}

National Cancer Institute

\section{Source}

National Cancer Institute. Selector Valve Device. NCI Thesaurus. Code C50258.

A valve designed to control which of several ports will be connected to a system. 